\title{
The Influence of Online Media and Social Media on Mass Communication with Communication Technology as Intervening Variables
}

\author{
Hafizah (Corresponding author) \\ Faculty of Economics and Business, Universitas Harapan, Medan, Indonesia \\ E-mail: hafizahhafis@gmail.com
}

Received: October 31, 2017 Accepted: November 15, 2017

doi:10.5296/ber.v8i1.12083 URL: https://doi.org/10.5296/ber.v8i1.12083

\begin{abstract}
This study aims to determine the Influence of Online Media and Social Media in North Sumatra to Mass Communication with Communication Technology as Intervening Variable. This type of research is descriptive quantitative. The independent variables are Online Media and Social Media. The intervening variable is Communication Technology and the dependent variable is Mass Communication. The population of this study is 203 users of Media Online and Social Media in North Sumatra. The sample of research is 203 users through purposive random sampling. Online Media and Social Media variables have a significant effect on Mass Communication in North Sumatra and Communication Technology serves as a mediation of the relationship between Media Online and Social Media to Mass Communication at 5\% variable alpha level.
\end{abstract}

Keywords: Online Media, Social Media, Communication Technology, and Mass Communication

\section{Introduction}

The development of cyberspace or the internet is very rapid. Currently, all conventional media in Indonesia are competing to make their online version as the number of internet users in Indonesia grows, which now reaches $25 \%$ of the total population of Indonesia (Rizky, 2012). Because of the emergence of Internet media, previous media such as television, radio, and print media now get a new name: the Mass Media Communications (Sadalia et al., 2017). In this era of globalization, journalist facilities in spreading information increases by one, that is online media. With the online media, people are able to provide information without limitation of space and time. The different fundamental characteristics of traditional media and online media poses various challenges faced by mass communicators in Indonesia. 
In addition, the development of Mobile Phone and WIFI now also has made it easier for people to access the internet. Media users in the move are required to be able to see and provide information on the facts that occur because all forms of information to other media users are expected to influence the recipient of the information to get feedback, where the responses are able to build a community that is intelligent and that care about the condition of the nation. It shows that the individual's trust to the media continues to grow, if the information needs that can not be found in the immediate experience is fulfilled. The mass is assessed to rely on Online and conventional media in this era of globalization. The more important the media to the individual, the higher the value of the media.

\section{Literature Review}

\subsection{The Characteristics of Online and Conventional Media}

The characteristics of the online media allow a direct reciprocal communication. In this way, media users can perform two way communication and interpersonal communication between media and user (Poell, 2014). Online media is free, unlimited, social-free, interference-free, and, of course, space and time-free, so do not be surprised if online media encourages manipulation in conveying information. Due to the absence of these restrictions, the online media's character refers to the anonymity of information makers in cyberspace. (Alejandro, 2010). On the one hand, this condition manifests in various negative things, such as black campaign to both personal and institutional. Many informations that should not be exposed and should not violate a person's or a company's rights circulate in cyberspace. Generally, the aggrieved parties can not prosecute who did the violation because of the anonymity (Macnamara, 2014).

\subsection{The Effects of Online Media and Social Media on Mass Communication}

Herng and Chang (2015) states that Online Media and Social Media facilitate the tasks and functions of journalists and tasks of Mass Communications. Tamimi (2015) also states that social media via social networking is a characteristic related to the journalistic environment. Online media and social media forms networks of journalistic functions. Currently, most of the average human activity requires online media and social media. Social media is the former and representation of every individual and social environment profile. Many media networks and social media are connected due to internet, email, and web based shortcuts (Clement and Dong, 2015). Although the online service community is always dependent on its provider network, but its users will always form group centers. Social media can always provide inspiration to share ideas, events, or other interesting things related to individual networks so that they are connected to each other and this enables journalists to use them in performing their mass communication tasks.

\subsection{The Role of Communication Technology in Mass Communication Tasks}

The competitiveness of a nation is determined by the mastery of knowledge and information technology or known as knowledge based economy (Muda et al., 2017). The development of the world economy has now turned to belong to the ruling states of information technology and communication, because they not only can receive the flow of information, but they are 
also able to process it in such a way to improve the nation's economy. (Schradie, 2015; Sadalia et al., 2017). Developments of technology facilitate public access to information dissemination, along with the emergence of social networking sites, i.e. twitter, facebook, friendster, myspace, and so forth, and blog provider sites, i.e. blogspot, wordpress, multiply and others. This container is then used by the community to disseminate the information it obtains. In broadcasting the information, the public is not limited by the rules and selection process, unlike the news process in conventional media. In conventional media, the facts that have been collected by media users are first collected and transferred to fellow media users (Clement and Dong, 2015). Benefits of advancement of information technology communications to media users is to send a fact automatically over the internet network. Thus, information technology plays a role in the needs of media users.

\subsection{Previous Research Review}

The matrix of the previous study which is almost related to this research can be seen in Table 1. below:

Table 1. Overview of Past Researches

\begin{tabular}{|c|c|c|c|c|c|}
\hline No. & Year & Name & Title & Variable & Research result \\
\hline 1. & 2014 & Al-Tamimi & $\begin{array}{l}\text { Demographic Factors } \\
\text { Influencing Arab Gulf Student's } \\
\text { Use of and Attitudes Toward } \\
\text { Social Network Services at } \\
\text { Ohio University; Field } \\
\text { Research on SNS Member's } \\
\text { Relationship }\end{array}$ & $\begin{array}{l}\text { Demographic Factors, } \\
\text { Social Network Services. }\end{array}$ & $\begin{array}{l}\text { Training and Development, On the Job } \\
\text { Training, Training Design and Delivery style } \\
\text { have significant affect on Organizational } \\
\text { Performance and all these have positively } \\
\text { affect the Organizational Performance. It } \\
\text { means it increases the overall Organizational } \\
\text { performance. We also prove our Hypothesis } \\
\text { through empirical data. However, the results } \\
\text { are strongly based on the literature review. }\end{array}$ \\
\hline 2 & 2014 & Ray, Paula & $\begin{array}{l}\text { Activism Via Social } \\
\text { Networking: A Case Study Of } \\
\text { Urban Indian Women Facebook } \\
\text { Users }\end{array}$ & $\begin{array}{l}\text { consciousness-raising } \\
\text { groups, civic awareness } \\
\text { groups and groups } \\
\text { promoting } \\
\text { participation }\end{array}$ & $\begin{array}{l}\text { The digital tool of activism has the potential to } \\
\text { unite the disparate waves of feminism, and in } \\
\text { fact, to herald the beginning of a new wave of } \\
\text { the feminist movement, initiated by digital } \\
\text { gadget-totting young women as well as men } \\
\text { who go online to voice their support. }\end{array}$ \\
\hline 3. & 2015 & $\begin{array}{l}\text { Fayomi, } \\
\text { Oluyemi O }\end{array}$ & $\begin{array}{l}\text { Transnational And Integrative } \\
\text { Cultural Roles of Nollywood } \\
\text { Entertainment Media In West } \\
\text { Africa: The Case Study of } \\
\text { Benin Republic And Ghana }\end{array}$ & $\begin{array}{l}\text { Promoters of Nollywood, } \\
\text { norms and cultures }\end{array}$ & $\begin{array}{l}\text { The benefits to the promoters of } \\
\text { Nollywood towards positive projection and } \\
\text { delivery of African values, norms and cultures } \\
\text { within West Africa, to other African countries, } \\
\text { so as to enhance the regional integration of } \\
\text { African Union. }\end{array}$ \\
\hline 4. & 2014 & $\begin{array}{l}\text { Poell, } \\
\text { Thomas. \& } \\
\text { José van } \\
\text { Dijck }\end{array}$ & $\begin{array}{l}\text { Social media and journalistic } \\
\text { independence. In } \\
\text { Media Independence: Working } \\
\text { with Freedom or Working for }\end{array}$ & $\begin{array}{l}\text { Enhance journalism's } \\
\text { democratic functions, } \\
\text { ndependent journalism }\end{array}$ & $\begin{array}{l}\text { Independent journalism once considered as } \\
\text { "independent from political and economic } \\
\text { power" and "representing the interests of } \\
\text { citizens.. }\end{array}$ \\
\hline
\end{tabular}




\begin{tabular}{|c|c|c|c|c|c|}
\hline & & & Free? & & \\
\hline 5. & 2010 & $\begin{array}{l}\text { Alejandro, } \\
\text { Jennifer }\end{array}$ & $\begin{array}{l}\text { Human Resource Policy } \\
\text { Journalism In The Age of } \\
\text { Social Media. }\end{array}$ & $\begin{array}{l}\text { Social networks, social } \\
\text { media, }\end{array}$ & $\begin{array}{l}\text { Journalism is not dead but merely adapting } \\
\text { and the journalists of the future need to } \\
\text { reinvent. Journalists surveyed confirm that } \\
\text { they are beginning to leverage on social media } \\
\text { to gather stories and use news aggregators }\end{array}$ \\
\hline 6 & 2015 & $\begin{array}{l}\text { Clement Y. K. } \\
\text { So and } \\
\text { Yuying Dong }\end{array}$ & $\begin{array}{l}\text { News Photos about Sichuan } \\
\text { Earthquake: Effects of Political } \\
\text { Ideology and Organizational } \\
\text { Goal }\end{array}$ & $\begin{array}{l}\text { Political ideology, } \\
\text { Organizational goal }\end{array}$ & $\begin{array}{l}\text { The clear political and ideological affiliations } \\
\text { of Xinhua News Agency and CCTV dictate } \\
\text { their roles in reporting the earthquake. The } \\
\text { difference in organizational goals between the } \\
\text { two mainland media organizations prescribe } \\
\text { what they actually did in their coverage of the } \\
\text { event. }\end{array}$ \\
\hline 7 & 2012 & $\begin{array}{l}\text { Newman, Nic; } \\
\text { William H. } \\
\text { Dutton and } \\
\text { Grant Blank }\end{array}$ & $\begin{array}{l}\text { Social Media in the Changing } \\
\text { Ecology of News: The Fourth } \\
\text { and Fifth Estates in Britain }\end{array}$ & $\begin{array}{l}\text { Internet, social media, } \\
\text { social network sites }\end{array}$ & $\begin{array}{l}\text { The Fourth Estate-the institutional news } \\
\text { media -is using social media to enhance their } \\
\text { role in news production and dissemination. }\end{array}$ \\
\hline 8 & 2015 & $\begin{array}{l}\text { Madianou, } \\
\text { Mirca; Liezel } \\
\text { Longboan and } \\
\text { Jonathan } \\
\text { Corpus Ong }\end{array}$ & $\begin{array}{l}\text { Finding a Voice Through } \\
\text { Humanitarian Technologies? } \\
\text { Communication Technologies } \\
\text { and Participation in Disaster } \\
\text { Recovery }\end{array}$ & $\begin{array}{l}\text { Voice, participation, new } \\
\text { communication } \\
\text { technologies, social media }\end{array}$ & $\begin{array}{l}\text { The article traces the } \\
\text { factors that facilitate, or hinder, participate and } \\
\text { find that communication technologies } \\
\text { enable voice only if other parameters, such } \\
\text { as a strong civil society, are present. }\end{array}$ \\
\hline 9 & 2015 & $\begin{array}{l}\text { Bolin, Göran } \\
\text { and Per } \\
\text { Ståhlberg }\end{array}$ & $\begin{array}{l}\text { Mediating the Nation-State: } \\
\text { Agency and the Media in } \\
\text { Nation-Branding Campaigns }\end{array}$ & $\begin{array}{l}\text { Nation branding, media } \\
\text { production, } \\
\text { technologies, }\end{array}$ & $\begin{array}{l}\text { The media (as technologies and organizations) } \\
\text { can shed light on the dynamics of nation } \\
\text { branding. }\end{array}$ \\
\hline 10 & 2015 & Schradie, Jen & $\begin{array}{l}\text { Political Ideology, Social } \\
\text { Media, and Labor Unions: } \\
\text { Using the Internet to Reach the } \\
\text { Powerful, Not Mobilize the } \\
\text { Powerless }\end{array}$ & $\begin{array}{l}\text { Political Ideology, Social } \\
\text { Media, and Labor Unions }\end{array}$ & $\begin{array}{l}\text { A radical union was bottom-up and } \\
\text { participatory, yet it had low levels of digital } \\
\text { engagement. This union viewed the Internet as } \\
\text { just one of many tools to organize the } \\
\text { powerless rather than a way to reach the } \\
\text { power. }\end{array}$ \\
\hline 11 & 2009 & $\begin{array}{l}\text { Hadi, } \\
\text { Prijana }\end{array}$ & $\begin{array}{l}\text { Modern Technology Journalism } \\
\text { and Covergence }\end{array}$ & $\begin{array}{l}\text { Modern journalism, } \\
\text { convergence, multimedia }\end{array}$ & $\begin{array}{l}\text { The most important structural new media } \\
\text { characteristic is the integration of } \\
\text { telecommunications, data communications and } \\
\text { mass communication in a single medium. It is } \\
\text { the process of } \\
\text { convergence. }\end{array}$ \\
\hline 12 & 2015 & $\begin{array}{l}\text { Herng Su and } \\
\text { Shi-Chung } \\
\text { Chang }\end{array}$ & $\begin{array}{l}\text { New Television and Old } \\
\text { Campaign: The Experience and } \\
\text { Lessons in Digital Television } \\
\text { Transition in Taiwan }\end{array}$ & $\begin{array}{l}\text { Digital switchover and } \\
\text { digital terrestrial television }\end{array}$ & $\begin{array}{l}\text { Digital transition process was not only a huge } \\
\text { transition with significant impact on } \\
\text { consumers, but also was, not until the last } \\
\text { moment, adequately planned for or } \\
\text { coordinated. }\end{array}$ \\
\hline
\end{tabular}




\subsection{Conceptual Framework}

The conceptual framework used in this research:

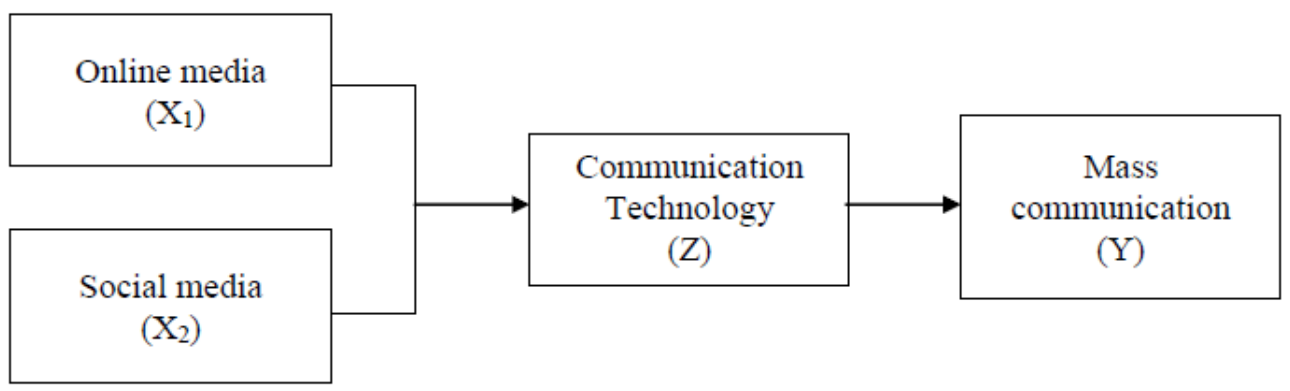

Figure 1. Conceptual Framework

The hypothesis of this research "Online Media and Social Media Influence on Mass Communication with Communication Technology as Intervening Variable"

\section{Research Method}

Research on things that are still foreign. Where researchers are not familiar with the problems studied. Usually this research is done by identifying people based on sociological and its role in society then the concept that has been made developed and revised what is thought does not match with the results obtained (Muda et al., 2014, Dalimunthe et al., 2016; Sirojuzilam et al. 2016; Handoko et al., 2017; Syahyunan et al., 2017, Nurlina et al., 2017 \& Yahya et al., 2017). This type of research is an exsplanatory survey. Exploratory research is a research that is still at the stage of identification (Muda, 2014). Researchers will be faced with problems that are not familiar. This research is intended to more researchers to know and develop the concept in accordance with the state of the field. So this study should not be done by people who are already proficient in the problem studied. For example researching about people who tend to be appreciated by other communities (Muda, 2017). By looking at the attitudes of citizens in society, their participation in community activities, up to the attitudes of citizens to themselves. After that the researchers set up categories on the subjects of the perpetrators and also categorize the events. From that category researchers can develop concepts in accordance with existing circumstances in the field (Muda and Dharsuky, 2015, Lubis et al., 2016; Ferine et al., 2017, Achmad et al., 2017, Dalimunthe et al., 2017 and Badaruddin et al., 2017). The design of this study is a survey with primary data survey results in the form of questionnaires distributed to the respondents. The population in this study is social media and online media users in North Sumatra. Sampling was done by purposive random sampling technique of 203 users of social media and online media. The operational definitions of each variable in this study are as follows: 


\section{Il Macrothink}

Business and Economic Research

ISSN 2162-4860

2018, Vol. 8, No. 1

Table 2. Operational Variables

\begin{tabular}{|c|c|c|c|c|}
\hline Variable & Variable & Indicator & Scale & Measurement \\
\hline $\begin{array}{l}\text { Online media } \\
\left(\mathrm{X}_{1}\right)\end{array}$ & $\begin{array}{l}\text { Media presented online on the } \\
\text { internet. }\end{array}$ & $\begin{array}{l}\text { 1. Access via internet. } \\
\text { 2. Mass communication. } \\
\text { 3. Periodicity. }\end{array}$ & Ordinal & Likert Scale \\
\hline $\begin{array}{l}\text { Social media } \\
\left(\mathrm{X}_{2}\right)\end{array}$ & $\begin{array}{l}\text { Online media and the users can } \\
\text { easily participate, share, and } \\
\text { create content including blogs, } \\
\text { social networks, wikis, forums } \\
\text { and virtual worlds. (Sadalia et al, } \\
2017 \text { and Marhayanie et al., } \\
2017 \text { ) }\end{array}$ & $\begin{array}{l}\text { 1. Internet based } \\
\text { 2. Building on an ideological } \\
\text { basis } \\
\text { 3. User-generated content }\end{array}$ & Ordinal & Likert Scale \\
\hline $\begin{array}{l}\text { Communication } \\
\text { Technology (Z) }\end{array}$ & $\begin{array}{l}\text { Hardware equipment, software } \\
\text { and communication networks } \\
\text { within an organizational structure } \\
\text { that contain social value allow } \\
\text { each individual to collect, process } \\
\text { and exchange information with } \\
\text { other individuals. (Stoval, 2004; } \\
\text { Muda } \text { et al., 2017) }\end{array}$ & $\begin{array}{l}\text { 1. Hardware equipment } \\
\text { 2. Software } \\
\text { 3. Communication network }\end{array}$ & Ordinal & Likert Scale \\
\hline $\begin{array}{l}\text { Mass } \\
\text { communication } \\
(\mathrm{Y})\end{array}$ & $\begin{array}{l}\text { Activities of media users in their } \\
\text { activities are required to be able } \\
\text { to see and provide information on } \\
\text { the reality that occurs to other } \\
\text { media users and able to influence } \\
\text { the recipient of information and } \\
\text { get feedback with the response. }\end{array}$ & $\begin{array}{l}\text { 1. Influence } \\
\text { 2. Value information } \\
\text { 3. Universality } \\
\text { 4. Feedback }\end{array}$ & Ordinal & Likert Scale \\
\hline
\end{tabular}

Data analysis method used to test the hypothesis in this research is the application of SEM (Structural Equation Model) Warp PLS. The equation is:

$$
\begin{gathered}
Y=\gamma_{11} X_{1}+\gamma_{12} X_{2}+\zeta \\
Z=\gamma_{11} X_{1}+\gamma_{12} X_{2}+\gamma_{13} Y+\zeta
\end{gathered}
$$

Information:

$$
\begin{array}{ll}
\xi & : \text { Measurement Error (epsilon)/Construct (ksi) } \\
\mathrm{Y} & : \text { Mass communication } \\
\mathrm{X} 1 & \text { : Online media } \\
\mathrm{X} 2 & \text { : Social media } \\
\mathrm{Z} & \text { : Communication Technology } \\
\gamma & \text { : Parameter (gamma) }
\end{array}
$$




\section{Result and Discussion}

\subsection{Result}

\subsubsection{Data Description}

The distribution of questionnaires is as follows:

Table 3. Distribution of Questionnaires

\begin{tabular}{|l|l|l|}
\hline Information & Quantity & Percentage \\
\hline The shared questionnaires & 500 & $100 \%$ \\
\hline The returned questionnaires & 203 & $40.60 \%$ \\
\hline The questionnaires that did not return & 297 & $59.40 \%$ \\
\hline Questionnaires that can be used in research & 203 & $40.60 \%$ \\
\hline
\end{tabular}

\subsubsection{Data Quality Testing Analysis}

\subsubsection{Validity Test}

From the results of questionnaires distributed to 203 respondents, output combined loading and cross loading are used as indicators of convergent validity that are parts of the measurement model in SEM-PLS (Kock, 2013; Muda et al., 2016 \& Lubis et al., 2016; and Sirojuzilam et al., 2017).

Table 4. Output Combined Loadings and Cross-Loading

\begin{tabular}{|c|c|c|c|c|c|c|c|}
\hline \multirow{2}{*}{\multicolumn{2}{|c|}{$\begin{aligned} & \text { OM_X } \\
& \text { MO1 } 0.920\end{aligned}$}} & \multirow{2}{*}{$\frac{\text { SM_X }}{-0.343}$} & CT_Z & \multicolumn{2}{|c|}{ JI_Y Type (a } & SE & $P$ value \\
\hline & & & 0.181 & -0.031 & Reflect & 0.047 & $<0.001$ \\
\hline MO2 & 0.892 & -0.601 & 0.972 & -0.275 & Reflect & 0.047 & $<0.001$ \\
\hline MO3 & 0.906 & 0.940 & -1.141 & $0.302 \mathrm{R}$ & & 0.047 & $<0.001$ \\
\hline MS1 & 0.969 & 0.891 & -0.814 & $0.355 \mathrm{R}$ & & 0.047 & $<0.001$ \\
\hline MS2 & -2.814 & 0.790 & 4.382 & -0.630 & Reflect & 0.048 & $<0.001$ \\
\hline MS3 & 1.807 & 0.751 & -3.639 & $0.241 \mathrm{R}$ & & 0.048 & $<0.001$ \\
\hline $\mathrm{Z} 1$ & 0.302 & -0.734 & 0.916 & -0.163 & Reflect & 0.047 & $<0.001$ \\
\hline $\mathrm{Z} 2$ & -0.170 & 0.086 & 0.883 & -0.058 & Reflect & 0.047 & 0.001 \\
\hline $\mathrm{Z3}$ & -0.140 & 0.661 & 0.902 & $0.222 \mathrm{R}$ & & 0.047 & $<0.001$ \\
\hline Y1 & 0.251 & 1.883 & -1.626 & $0.840 \mathrm{R}$ & & 0.047 & $<0.001$ \\
\hline Y2 & -0.418 & 0.309 & 0.244 & $0.830 \mathrm{R}$ & & 0.048 & $<0.001$ \\
\hline Y3 & 0.163 & -0.670 & 0.333 & $0.939 \mathrm{R}$ & & 0.047 & $<0.001$ \\
\hline Y4 & -0.019 & -1.339 & & & 3Reflect & 0.047 & $<0.001$ \\
\hline
\end{tabular}

Notes: Loadings are unrotated and cross-loadings are oblique-rotated. SEs and P values are for loadings. $\mathrm{P}$ values $<0.05$ are desirable for reflective indicators.

Source: Output WarpPLS 5.0. (2017). 


\section{Macrothink}

Business and Economic Research

ISSN 2162-4860

2018, Vol. 8, No. 1

Based on the test results, it is shown that the outer model qualifies the convergent validity for reflective constructs, where loading values are above 0.70 and the p-value is significant (<0.05) (Sadalia et al., 2017; Lubis et al., 2017 and Muda et al., 2017). The results of the test construct meet the requirements of convergent and loading validity to other constructs that are lower than those constructs (Sholihin, 2013).

\subsubsection{Reliability Test}

Based on WarpPLS output, reliability test results are as follows:

\section{Cronbach's alpha coefficients}

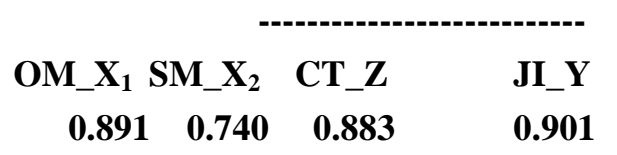

Source: Output WarpPLS 5.0. (2017).

Based on the results of reliability test against 4 (four) constructs, Cronbach's Alpha obtained is above $60 \%$, so all questions are stated reliable.

\subsubsection{Goodness of Fit Model Test}

The fit model indicator is based on several indicators. Test results show:

\section{Model fit indices and $P$ values}

Average path coefficient $(\mathrm{APC})=0.455, \mathrm{P}<0.001$

Average R-squared $(\mathrm{ARS})=0.884, \mathrm{P}<0.001$

Average adjusted R-squared (AARS) $=0.884, \mathrm{P}<0.001$

Average block VIF $($ AVIF $)=2.942$, acceptable if $<=5$, ideally $<=3.3$

Average full collinearity VIF (AFVIF) $=1.122$, acceptable if $<=5$, ideally $<=3.3$

Tenenhaus GoF $(\mathrm{GoF})=0.823$, small $>=0.1$, medium $>=0.25$, large $>=0.36$

Sympson's paradox ratio $(\mathrm{SPR})=1.000$, acceptable if $>=0.7$, ideally $=1$

R-squared contribution ratio $(\mathrm{RSCR})=1.000$, acceptable if $>=0.9$, ideally $=1$

Statistical suppression ratio $(\mathrm{SSR})=1.000$, acceptable if $>=0.7$

Nonlinear bivariate causality direction ratio $=1.000$, acceptable if $>=0.7$

Source : Output WarpPLS 5.0. (2017).

Thus, all model indicators meet the fit criteria.

\subsubsection{Multicolinearity Test}

Based on correlation test results among independent variables by looking at VIF values, it can be concluded that there is no multicollinearity problem. This is supported by the 


\section{Macrothink}

relatively small Full Collon VIF value, i.e. nothing greater than 3.3 (Kock, 2013)

Table 5. Multicolinearity Test Results (Full collinearity VIFs)

$\begin{array}{crrr}\text { OM_X } & \text { SM_X } & \text { CT_Z } & \text { JI_Y } \\ 1.906 & 1.807 & 2.885 & 2.889\end{array}$

Source : Output WarpPLS 5.0. (2017).

These results conclude that in all independent variables, there is no multicollinearity where the overall AVIF value is less than 5 (Kock, 2013).

\subsubsection{Hypothesis Testing}

The hypothesis states that Online Media and Social Media in North Sumatra have an effect on Mass Communication with Communication Technology as Intervening Variable in North Sumatera. Individual coefficient test of each independent variable can be seen in the following figure:

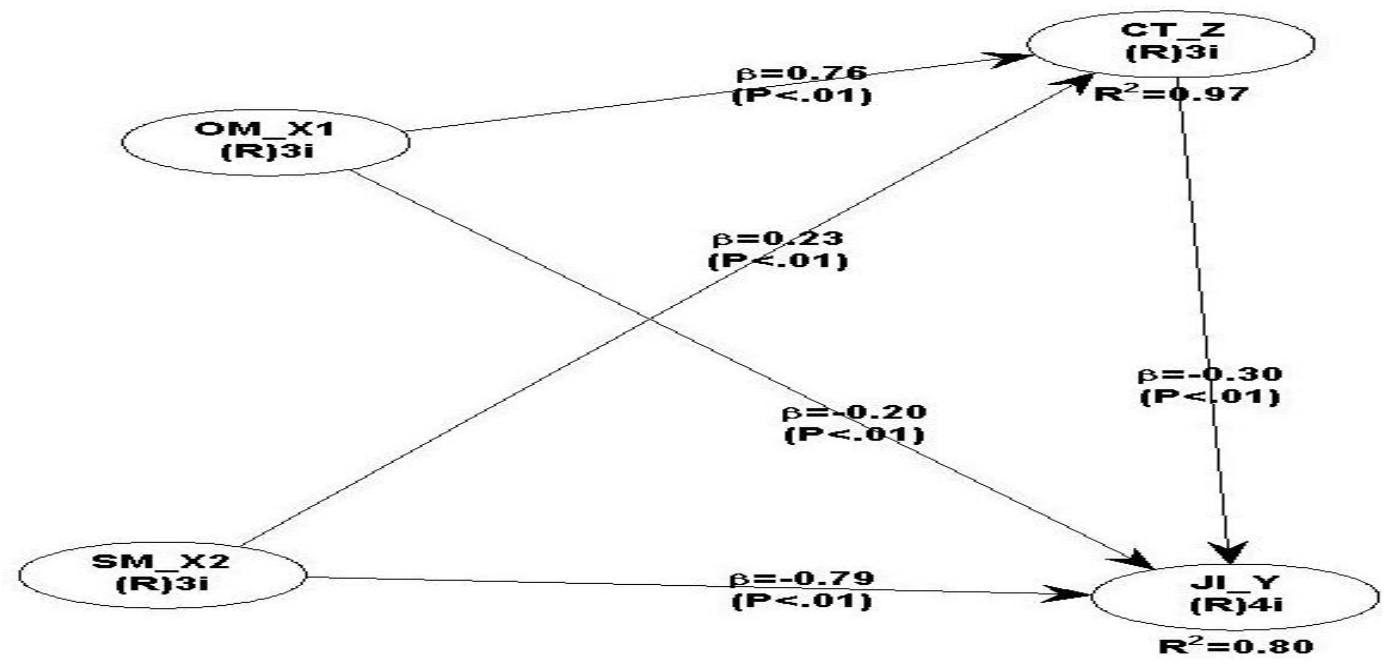

Figure 2. Test Results

The statistical Test $\mathrm{t}$ obtains:

1. The beta value of the Online Media Variable $\left(\mathrm{X}_{1}\right)$ is 0.20 and the probability level of $\mathrm{p}$-value is 0.01 . Thus, it can be concluded $\mathrm{p}=0.001<\alpha=0.05$, the hypothesis $\mathrm{H} 0$ is rejected and the hypothesis Ha is accepted (Muda, 2010; Maksum et al., 2014; Nasir et al., 2014; Sihombing et al., 2015; Suriadi et al., 2015), which states the variable Online Media has a significant positive effect on Mass Communication.

2. The beta value of Social Media Variable $\left(\mathrm{X}_{2}\right)$ is 0.79 and the probability level of p-value is 0.01 . Thus, it can be concluded $\mathrm{p}=0.001<\alpha=0.05$ (Sirojuzilam et al., 2016; Lubis et al., 2016; Muda, 2017). Thus, it can be concluded that the hypothesis H0 is rejected and the hypothesis Ha is accepted, which states Social Media variables have a significant effect on Mass Communication.

3. The beta value of the Communication Technology Variable $(Z)$ is -0.30 and the probability level of p-value with is 0.01 . Thus, it can be concluded $\mathrm{p}=0,01<\alpha=0,05$. Thus, it can be concluded that the hypothesis $\mathrm{H}_{0}$ 
is rejected and the hypothesis Ha is accepted, which states the variables of Communication Technology mediate relationship to Mass Communication.

From the description above, then thus, it can be composed of multiple regression equation sourced from the path coefecient as follows:

$$
\mathrm{Y}=0.20 \mathrm{X}_{1}+0.79 \mathrm{X}_{2}-0.30 \mathrm{Z}+\mathrm{e}
$$

\subsubsection{Coefficient Determination Test Results $\left(\mathrm{R}^{2}\right)$}

The magnitude coefficient of determination equation is:

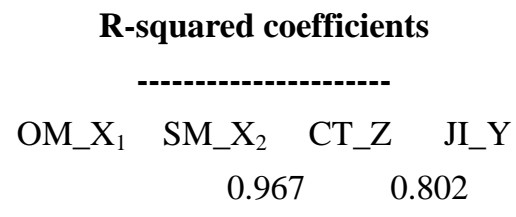

Source : WarpPLS 5.0 Output Results(2017)

From the calculation, the value of $\mathrm{R}$ Square is 0.802 . This means that 80.2 percent of Media Online and Social Media variables affect Mass Communication and it can be explained by independent variables, while the remaining $19.8 \%$ is explained by other factors outside the model.

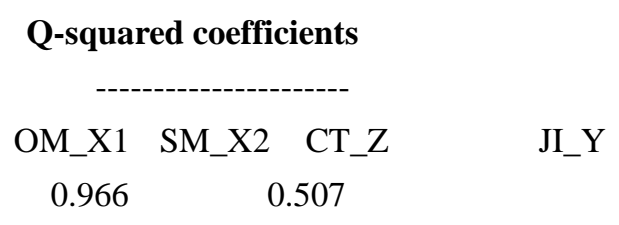

Source : WarpPLS 5.0 Output Results (2017)

While the value of Q-squared is 0.507 , which means the model estimation shows good predictive validity of $50.7 \%$.

\subsection{Discussion}

It cannot be denied that the development of information technology greatly affect communication technology. Information and communication technology can not be separated, so Information and Communication Technology is very popular right now. The combination of both grows rapidly with the Internet media. Internet technology has changed the way people communicate (Muda and Dharsuky, 2015). Email is the key in changing how to communicate. With just one email address, one can follow various communication models on the Internet. Barney (2005) states that improving the quality of life increasingly demands humans to perform various activities needed by optimizing the resources it has. Information and Communication Technology grows so fast, indirectly it requires humans to use it in all activities (Gusnardi et al., 2016 \& Muda et al., 2017). For media users, the role of Information Technology (IT) is very important, with IT like the Internet, the information created will be quickly accessed by others. With IT, a media user will get instant information and it is directly accessible to others for a source of information used in their various life 
needs and work completion (Sadalia et al., 2017). So information technology (IT) is a big influence. Due to the development of Information Technology, journalism will definitely change following the rate of development of Information Technology (Muda et al., 2014, Hadi, 2005 \& Muda et al., 2017). Technology in the development of the flow of production, consumption, and distribution of information plays an important role. The role of technology in the process of information processing occurs when technology results help to change the communication patterns that are bounded by space and time into a pattern of unlimited information communication. Thus, the presence of new media provides an alternative for the community in finding and utilizing information sources to meet their needs (Khaldun and Muda, 2014; Radianto et al., 2014 \& Lutfi et al., 2016; Erlina et al., 2017 \& Hasan et al., 2017). Media users can send news instantly and simultaneously in context with global coverage. The information stored online has a quality that is so powerful, easy to trace (retrievability), but also prone to be duplicated. Because the web is an open medium and a networked technology, so it is easily duplicated and stored in a different location from the original.

\section{Conclusions and Recommendations}

\subsection{Conclusion}

Hypothesis which states that Online Media and Social Media Influence on Mass Communication with Communication Technology as Intervening Variable.

\subsection{Suggestion}

Future research is expected to expand the object of research, especially in the scope of Indonesia and the comparison with media users abroad.

\section{References}

Achmad, Nurman, \& Muda, I. (2017). Economic Activities of Karo Older Adults in Lingga Village, Tanah Karo Regency, North Sumatera, Indonesia. International Journal of Economic Research, 14(16), 365-379.

Alejandro, Jennifer. (2010). Journalism In The Age of Social Media. Reuters Institute Fellowship Paper University of Oxford.

Al-Tamimi. (2014). Demographic Factors Influencing Arab Gulf Student's Use of and Attitudes Toward Social Network Services at Ohio University; Field Research on SNS Member's Relationship. International Journalism Mass Communication, 2, 110. http://dx.doi.org/10.15344/2349-2635/2015/110.

Azlina, Nur. Amir Hasan, Desmiyawati, \& Muda, I. (2017). The Effectiveness of Village Fund Management (Case Study at Villages in Coastal Areas in Riau). International Journal of Economic Research, 14(12), 325-336.

Badaruddin, Revida, Ermansyah, E., \& Muda, I. (2017). Village Governance With Implementation of Law Number 6 of 2014 On The Village and Village Administration. International Journal of Economic Research, 14(16), 350-363. 
Barney, Darin. (2005). Communication Technology. UBC Press. Canada.

Bolin, Göran and Per Ståhlberg. (2015). Mediating the Nation-State: Agency and the Media in Nation-Branding Campaigns. International Journal of Communication, 9(2), 3065-3083.

Clement Y. K. So., \& Yuying Dong. (2015). News Photos about Sichuan Earthquake: Effects of Political Ideology and Organizational Goal. International Journalism Mass Communication, 1, 108. https://doi.org/10.15344/2349-2635/2014/108.

Dalimunthe, D. M J., Fadli, \& Muda, I. (2016). The application of performance measurement system model using Malcolm Baldrige Model (MBM) to support Civil State Apparatus Law (ASN) number 5 of 2014 in Indonesia. International Journal of Applied Business and Economic Research, 14(11), 7397-7407.

Dalimunthe, D. M. J., \& Muda, I. (2017). The Empirical Effect of Education and Training to The Performance of Employees. International Journal of Applied Business and Economic Research, 15(24). 5423-5437.

Erlina, Ari Saputra, \& Muda, I. (2017). Antecedents of Budget Quality Empirical Evidence from Provincial Government In Indonesia. International Journal of Economic Research, 14(12), 301-312. Available

http://serialsjournals.com/articles.php?volumesno_id=1332\&journals_id=41\&volumes_id=10 68. (October 1, 2017)

Erlina. Ari Saputra \& Muda, I. (2017). The Analysis of the Influencing Factors of Budget Absorption. International Journal of Economic Research. 14(12). 287-300. Available http://serialsjournals.com/articles.php?volumesno_id=1332\&journals_id=41\&volumes_id=10 68. (October 1, 2017)

Fayomi, Oluyemi O. (2015). Transnational And Integrative Cultural Roles of Nollywood Entertainment Media In West Africa: The Case Study of Benin Republic And Ghana. International Journal of International Relations, Media and Mass Communication Studies, $1(1), 34-41$.

Ferine, Kiki Farida; Ermiaty, C., \& Muda, I. (2017). The Impact Of Entrepreneurship And Competence On Small Medium Enterprises Tangan Di Atas (TDA) Medan Entrepreneurs' Work Performance. International Journal of Economic Research, 14(16), 380-393.

Gusnardi, Riadi, R. M., \& Muda, I. (2016). Competency mapping and analysis of students competency based on economics subject national examination and its alternative solutions in state high schools at Pekanbaru. International Journal of Economic Research, 3(5). 2133-2148.

Hadi, Ido Prijana. (2009). Perkembangan Teknologi Komunikasi dalam Era Jurnalistik Modern. Jurnal Ilmiah SCRIPTURA, 3(1). 69-84.

Handoko, Bagus. Sunaryo, \& Muda, I. (2017). Difference Analysis of Consumer Perception of Motorcycle Product Quality. International Journal of Economic Research, 14(12). 363-379. 


\section{$\triangle 1$ Macrothink}

Business and Economic Research ISSN 2162-4860 2018, Vol. 8, No. 1

Hasan, Amir, Gusnardi \& Muda, I. (2017). Analysis of Taxpayers and Understanding Awareness Increase in Compliance with Taxpayers Individual Taxpayers. International Journal of Economic Research, 14(12), 75-90.

Herng Su \& Shi-Chung Chang. (2015). New Television and Old Campaign: The Experience and Lessons in Digital Television Transition in Taiwan. International Journalism Mass Communication, 2, 111. https://doi.org/10.15344/2349-2635/2014/108.

Kaplan, Andreas M.; Michael Haenlein. (2010). Users of the world, united The challenges and opportunities of Social Media. Business Horizons, 53(1), 59-68.

https://doi.org/10.1016/j.bushor.2009.09.003

Khaldun, Khalidazia Ibnu and Iskandar Muda. (2014). The Influence of Profitability And Liquidity Ratios on The Growth of Profit of Manufacturing Companiesa Study of Food And Beverages Sector Companies Listed on Indonesia Stock Exchange (Period 2010-2012). International Journal of Economics, Commerce and Management, 2(12), 1-17.

Kock, Ned. (2013). Advanced Mediating Effects Tests, Multi-Group Analyses, and Measurement Model Assessments in PLS-based SEM. ScriptWarp Systems- Laredo, Texas USA.

Lubis, A. F., Lubis, T. A., \& Muda, I. (2016). The role of Enterprise Resource Plan (ERP) configuration to the timeliness of the financial statement presentation. International Journal of Applied Business and Economic Research, 14(11). 7591-7608. Available

http://www.serialsjournals.com (October 1, 2017)

Lubis, A., Rustam and Muda, I. (2017). Factors Affecting The Cost of Agency of Village Owned Enterprise (BUMDES) in Indonesia. International Journal of Economic Research, 14(16). 334-348. Available

http://www.serialsjournals.com/serialjournalmanager/pdf/1502169155.pdf. (October 1, 2017)

Lubis, A., Torong, Z. B., \& Muda, I. (2016). The urgency of implementing balanced scorecard system on local government in North Sumatra - Indonesia. International Journal of Applied Business and Economic Research, 14(11). 7575-7590. Available

http://serialsjournals.com/serialjournalmanager/pdf/1481524509.pdf. (October 1, 2017)

Lutfi, M., Nazwar, C., \& Muda, I (2016). Effects of investment opportunity set, company size and real activity manipulation of issuers in Indonesia Stock Exchange on stock price in Indonesia. International Journal of Economic Research, 13(5), 2149-2161.

Macnamara, Jim. (2014). Media Mana Yang Menentukan Pemberitaan? Media Massa atau/dan Media Sosial?. Sentia Publisher. Jakarta.

Madianou, Mirca; Liezel Longboan and Jonathan Corpus Ong. (2015). Finding a Voice Through Humanitarian Technologies? Communication Technologies and Participation in Disaster Recovery. International Journal of Communication, 9(1), 3020-3038.

Mahdaleta, Ela; Iskandar Muda and Gusnardi Muhammad Nasir. (2016). Effects of Capital Structure and Profitability on Corporate Value with Company Size as the Moderating 


\section{MlMacrothink}

Business and Economic Research ISSN 2162-4860 2018, Vol. 8, No. 1

Variable of Manufacturing Companies Listed on Indonesia Stock Exchange. Academic Journal of Economic Studies, 2(3), 30-43.

Maksum, A., Hamid, R., \& Muda, I. (2014). The Impact of Treasurer's Experience And Knowledge on The Effectiveness of The Administration and Preparation of The Accountability Reporting System in North Sumatera. Asian Journal of Finance \& Accounting, 6(2), 301-318. https://doi.org/10.5296/ajfa.v6i2.6341.

Marhayanie, Mutia Ismail \& Muda, I, (2017). Impact of The Online Car Rental Service Order System on Sales Turnover with Financial Literacy Customer as Intervening Variables. International Journal of Economic Perspectives, 14(16), 317-332.

Marlon Sihombing; Muda, I, Erni Jumilawati and Abikusno Dharsuky. (2017). Factors Affecting The Success Of Local Innovation Systems With Government Programs As Moderators. International Journal of Economic Research, 14(16), 272-289.

Muda, I and Abykusno Dharsuky, (2016). Impact of Capital Investments and Cash Dividend Policy on Regional Development Bank (BPD) PT. Bank Sumut to the District Own Source Revenue and Economic Growth. International Journal of Applied Business and Economic Research, 14(11), 7863-7880.

Muda, I, Deni Yuwilia Wardani, Erlina, Azhar Maksum, Ade Fatma Lubis, \& Rina Bukit. (2017). The Influence of Human Resources Competency \& The Use of Information Technology on The Quality of Local Government Financial Report with Regional Accounting System as an Intervening. Journal of Theoretical \& Applied Information Technology, 95(20), 1432-1451. Available http://www.jatit.org/volumes.php (October 1, 2017)

Muda, I, Dharsuky. A., Siregar, H. S., \& Sadalia, I. (2017). combined loading and Cross-dimensional loadings timeliness of presentation of financial statements of local government. IOP Conference Series: Materials Science and Engineering, 180. https://doi.org/10.1088/1757-899X/180/1/012099

Muda, I, Marlon Sihombing, Erni Jumilawati and Abikusno Dharsuky. (2016). Critical Success Factors Downstream Palm Oil Based Small And Medium Enterprises (SME) In Indonesia. International Journal of Economic Research, 13(8), 3531-3538. Available http://serialsjournals.com/serialjournalmanager/pdf/1499428227.pdf. (October 1, 2017)

Muda, I, Mutia Ismail \& Marhayanie. (2017). Impact Allocation Capital Expenditure on The Improvement of the Local Government Assets in North Sumatra and Effect on Local Revenue Sustainability. International Journal of Economic Perspectives, 11(2), 151-164.

Muda, I, Rahmanta, S. Adi, \& Marhayanie (2017). The Role of Working Capital, Productivity, Applied Technology and Selling Market Prices on Fisherman's Revenues. International Journal of Economic Research, 14(16), 291-302. Available

http://www.econ-society.org/ijep_contents_11.2.php. (October 1, 2017)

Muda, I. (2014). Analysis on the Timeliness of the Accountability Report by the Treasurer Spending in Task Force Units in Indonesia. International Journal of Academic Research in 
Accounting, Finance and Management Sciences, 4(4), 176-190.

Muda, I., \& Abykusno Dharsuky. (2015). Impact Of Region Financial Information System (SIKD) Quality, Role Ambiguity And Training on Precision of Financial Statement of Local Government Presentation In North Sumatra. International Journal of Applied Business and Economic Research, 13(6), 4283-4304.

http://www.serialsjournals.com/articles.php?volumesno_id=919\&journals_id=22\&volumes_i $\mathrm{d}=788$. (October 1,2017 )

Muda, I., \& Rasdianto, M. S. L. (2014). Implementation of the Cash Revenue System: A Case Study in the Local Government Task Forces' Units of North Sumatera Province, Indonesia. Information Management \& Business Review, 6(2), 96-108.

Muda, I., (2017). Perception of capital, profit and dividends affect the stock purchase intention in Indonesia public company. Junior Scientific Researcher, 3(1). 9-18. Available www.jsr.ro (October 1, 2017)

Muda, I., Rafiki, A., \& Harahap, M. R. (2014). Factors Influencing Employees' Performance: A Study on the Islamic Banks in Indonesia. International Journal of Business and Social Science, 5(2), 73-80.

Muda, I., Weldi, M., Siregar, H. S., \& Indra, N. (2017). The Analysis of Effects of Good Corporate Governance on Earnings Management in Indonesia with Panel Data Approach. Iranian Economic Review, 21(4), 657-669.

Muda, Iskandar \& Ahmad Rafiki. (2014). Human Resources Development and Performance of Government Provincial Employees: A Study in North Sumatera, Indonesia. Journal of Economics and Behavioral Studies, 6(2), 152-162.

Muda, Iskandar, (2017). The Effect of Allocation of Dividend of the Regional Government-Owned Enterprises and the Empowerment Efforts on the Revenue of Regional Government: The Case of Indonesia. European Research Studies Journal, XX(3A), 223-246.

Muda, Iskandar, (2017). The Effect of Supervisory Board Cross-Membership and Supervisory Board Members' Expertise to The Disclosure of Supervisory Board's Report : Empirical Evidence From Indonesia. European Research Studies Journal, XX(3A), 702-716.

Muda, Iskandar, Erlina, Rina Bukit and Rahmanta. (2015). The Effect of Fiscal Potential, Fiscal Needs and Internal Control on The Provincial Intergovernmental Transfer Allocation In The Districts/Cities in North Sumatera - Indonesia. International Journal of Management Sciences and Business Research, 3(10), 22-35. http://www.jatit.org/volumes.php

Muda, Iskandar. (2010). Contribution of Teluk Nibung Port Tanjung Balai Asahan to The Local Revenue of Tanjung Balai City. Journal of Economics and Business, 9(1). 17-28.

Muda, Iskandar. (2017). Role of Dividend of Power to Buy Shares in Companies in Indonesia Stock Exchange. Academic Journal of Economic Studies, 3(2), 41-47.

Muda, Iskandar. (2017). User Impact of Literacy on Treatment Outcomes Quality Regional 
Financial Information System. Management Dynamics in the Knowledge Economy, 5(2). 307-326. https://doi.org/10.25019/MDKE/5.2.08

Nasir, Azwir. Yesi Mutia Basri, Kamaliah \& Muda, I. (2017). Effectiveness of Potential Tax Region as the Real Local Revenue Sources in Riau Coastal Area. International Journal of Economic Research, 14(12). 313-324.

Newman, Nic; William H. Dutton \& Grant Blank. (2012). Social Media in the Changing Ecology of News: The Fourth and Fifth Estates in Britain. International Journal of Internet Science, 7(1). 6-22.

Nurlina and Muda, I. (2017). The Analysis of The Effects of Capital Expenditure and Human Development Index on Economic Growth and Poverty in East Aceh Regency. International Journal of Economic Research, 14(16). 395-409.

Nurzaimah, Rasdianto \& Muda, I. (2016). The skills and understanding of rural enterprise management of the preparation of financial statements using Financial Accounting Standards (IFRs) financial statement on the Entities without Public Accountability (ETAP) framework on the implementation of village administration law. International Journal of Applied Business and Economic Research, 14(11), 7417-7429.

Poell, Thomas. \& José van Dijck. (2014). Social media and journalistic independence. In Media Independence: Working with Freedom or Working for Free?, edited by James Bennett \& Niki Strange. 182-201. London: Routledge.

Rasdianto, Nurzaimah \& Iskandar Muda. (2014). Analysis on the Timeliness of the Accountability Report by the Treasurer Spending in Task Force Units in Indonesia. International Journal of Academic Research in Accounting, Finance and Management Sciences, 4(4), 176-190. https://doi.org/10.6007/IJARAFMS/v4-i4/1304.

Ray, Paula. (2014). Activism Via Social Networking: A Case Study of Urban Indian Women Facebook Users. Available: http://researchspace.auckland.ac.nz/feedback. (September 7, 2017).

Risky, Annisa. (2012). The Influence of Online Media on The Role of Journalists. Retrieved fromhttp://annisarisky.blogspot.co.id/2012/04/pengaruh-media-online-terhadapperan.html. Accesed on September, 172017.

Sadalia, Isfenti. Nur Ahmadi Bi Rahamani \& Muda, I. (2017). The Significance of Internet Based Financial Information Disclosure on Corporates' Shares in Indonesia. International Journal of Economic Research, 14(12), 337-346.

Schradie, Jen. (2015). Political Ideology, Social Media, and Labor Unions: Using the Internet to Reach the Powerful, Not Mobilize the Powerless. International Journal of Communication, 9(1), 1985-2006.

Sholihin, Mahfud \& Dwi Ratmono. (2013). SEM-PLS Analysis with WarpPLS 3.0 for Non-Linear Relationships in Social and Business Research. Andi Publisher. Yogyakarta. 


\section{I Macrothink}

Business and Economic Research ISSN 2162-4860 2018, Vol. 8, No. 1

Sihombing, Marlon, Iskandar Muda, Erni Jumilawati, Abikusno Dharsuky. (2015). The Implementation of Oil Palm Based Regional Innovation System (SIDA) In Supporting The Masterplan For The Acceleration And Expansion of Indonesia's Economic Development (MP3EI) of The Economic Corridor Of Sumatera-Indonesia. European Journal of Business and Innovation Research, 3(5), 13-24.

Sirojuzilam, Hakim, S., \& Muda, I. (2016). Identification of factors of failure of Barisan Mountains Agropolitan area development in North Sumatera - Indonesia. International Journal of Economic Research, 13(5), 2163-2175.

Sirojuzilam, Hakim, S., and Muda, I. (2017). Effect of Private Collaborative as a Moderation of Success of Agropolitan Program. International Journal of Economic Research, 14(16). 304-315.

Stovall, James Glen. (2004). Web Journalism of a New Medium.: Pearson Education Inc. University of Alabama.

Suriadi, Agus, Rudjiman, Kasyful Mahalli, Nurman Achmad and Iskandar Muda. (2015). The Applicative Model of The Village_Owned Enterprises (BUMDES) Development In North Sumatera. Global Journal of Arts, Humanities and Social Sciences, 3(12), 48-62.

Syahyunan, Muda'I, Siregar, H. S, Sadalia, I., \& Chandra, G. (2017). The Effect of Learner Index and Income Diversification on The General Bank Stability In Indonesia. Banks and Bank Systems, 12(4), 171-184.

Tarmizi, H. B., Daulay, M., \& Muda, I. (2016). The influence of population growth, economic growth and construction cost index on the local revenue of tax on acquisition of land and building after the implementation of law no. 28 of 2009. International Journal of Economic Research, 13(5), 2285-2295. Available

http://www.serialsjournals.com/serialjournalmanager/pdf/1502169196.pdf. (July 20, 2017)

Tarmizi, HB., Daulay, M., \& Muda, I. (2017). Impact of The Economic Growth and Acquisition of Land to The Construction Cost Index in North Sumatera. IOP Conference Series : Materials Science and Engineering. 180.

Yahya, I, Torong, Z. B., \& Muda, I. (2017). Influence Behavior in Legislature Budget Development of Regions in the Province of Aceh and North Sumatra. International Journal of Economic Research, 14(8), 147-159.

\section{Copyright Disclaimer}

Copyright for this article is retained by the author(s), with first publication rights granted to the journal.

This is an open-access article distributed under the terms and conditions of the Creative Commons Attribution license (http://creativecommons.org/licenses/by/3.0/). 